\title{
Market Orientation of News Startups
}

Christoph Sommer

The media industry is undergoing major disruptions, which foster innovation; however, this makes starting a new business particularly difficult. In this unstable environment, theory suggests market orientation as being important for success. Based on four case studies of early stage news startups, this study investigates the processes and practices of market orientation in the media. The results show that startups generate market intelligence in various ways and, in doing so, they prioritize the markets. Most of the attention has been dedicated to learning about users, while placing less effort on examining businesses and competitors. Overall, market orientation seems to have a positive influence on news startups' survival and support innovation.

Keywords

Market orientation, innovation, news startups

The Journal of Media Innovations 4.2 (2018),34-54

\section{INTRODUCTION}

The media industry is undergoing major disruptions which force media outlets to innovate (Boczkowski, 2004; McKelvie \& Wiklund, 2008; Westlund \& Lewis, 2014). The audience's consumption patterns are changing, advertisers' budgets are shifting, and new competition is arising, e.g. in the form of tech companies. This unstable and uncertain environment makes starting a new business and bringing a new service to the market difficult. In doing so, market orientation theory suggests that customer orientation, competitor orientation, and interfunctional coordination are important for success (Jaworski \& Kohli, 1993; Narver \& Slater, 1990).

However, research and insights about market orientation in news media and market orientation when starting a news media business are limited. Three reasons contribute to this shortcoming in the literature. First, there is a lack of research about entrepreneur- ship in the media, despite startups potentially being most innovative (Achtenhagen, 2008; Compaine \& Hoag, 2012; McKelvie \& Wiklund, 2008). Second, the findings from other industries are difficult to transfer to the media business because of media's distinct characteristics (Dogruel, 2014). Third, prior studies have focused on market orientation in newsrooms, while disregarding a more holistic approach which includes a media management perspective (Beam, 2001; Sommer \& Krebs, 2016; Tandoc \& Ferrucci, 2014)

Consequently, news startups and their market orientation are the focus of the present study. The goal is to explore and analyze the practices and processes of market orientation in new and young media outlets in the fields of content creation, curation, and aggregation, which compete with traditional players in serving the audience's needs for information. This study investigates how market intelligence is gener- 
ated and used on the basis of four case studies of early stage startups. This research responds to the void of literature on market orientation in the media. From an academic perspective, these insights are needed to improve the holistic understanding of the theory in a specific industry. For media practice, this study provides evidence about the importance of market orientation when starting a media business.

The structure of the paper is as follows: The literature review summarizes market orientation theory and assesses the construct's importance for new product development and innovation. Entrepreneurship in the media is explored, before connecting market orientation theory with the media industry in general und news startups in particular. The method section describes the case study approach in further detail. Subsequently, results are summarized and discussed regarding the support and contradiction of existing studies. Finally, implications for further research are presented, followed by the conclusion.

\section{LITERATURE REVIEW}

Market Orientation Theory

Market orientation "is the organization-wide generation of market intelligence pertaining to current and future customer needs, dissemination of the intelligence across departments, and organizationwide responsiveness to it" (Kohli \& Jaworski, 1990, p. 6). Following Narver and Slater (1990), market orientation consists of three behavioral components: customer orientation, competitor orientation, and interfunctional coordination, which are important for long-term profit (Narver \& Slater, 1990). Originally, the cultural (Kohli \& Jaworski, 1990) and the behavioral (Narver \& Slater, 1990) perspectives have been distinguished. While the former defines market orientation as a mindset and corporate culture of the organization, the latter focuses on concrete instruments, tools, and behaviors. However, the two conceptualizations share many underlying concepts (Noble, Sinha, \& Kumar, 2002) and they are very similar in their operationalization (Cadogan \& Diamantopoulos, 1995). Consequently, they have been combined in more recent studies (Baumgarth, 2009; Brïdson \& Evans, 2004; Homburg \& Pflesser, 2000). Market-oriented companies are characterized through capabilities such as collecting knowledge regarding the needs and processes on the customer side (Danneels, 2002; Day, 1994). They also learn about their environment through the analysis of strengths and weaknesses as well as emerging markets and competitors (Narver \& Slater, 1990; Slater $\&$ Narver, 1995). In order to succeed, this information is shared across functions and the use of resources is coordinated to create superior value for the customer (Narver \& Slater, 1990).

Prior research on market orientation assumed that it was a key factor in times of uncertainty (Ja- worski \& Kohli, 1993; Li \& Calantone, 1998). Wren, Souder, and Berkowitz (2000, p. 602) add to this argument by stating: "There is research to suggest that the skills that comprise market orientation (organizational support/systems, market knowledge, interconnectedness, etc.) are more important in industries characterized by rapid technology change, competitive intensity, and market uncertainty."

Uncertainty is particularly high when starting a new business or developing a new product or service. Market-oriented companies are in touch with the market, have a better understanding of their customers' wants and needs, and possess a greater knowledge of the competition and trends in the market place, which allows them to maximize the probability of success when developing and introducing new products (Wren et al., 2000). Hong, Song, and Yoo (2013) find a positive effect of market orientation on new product performance. Wong and Tong (2012) explicitly look at the influence of customer and competitor orientation. They find that both have a significant positive effect on new product success.

For new businesses and products, the relationship of market orientation and innovation is extremely important. While some scholars argue that market orientation has negative consequences as it leads to the creation of "me-too" products, others claim that it is crucial for successful innovation and organizational performance (Atuahene-Gima, 1996; Orda- 
nini \& Maglio, 2009). To resolve this controversy, Atuahene-Gima (1996) shows market orientations effect on innovation characteristics such as product newness (negative), innovation fit (positive), product advantage (positive), and interfunctional teamwork (positive) as well as a positive relationship between market success and project impact performance. Han, Kim, and Srivastava (1998) provide evidence that market orientation facilitates an organization's innovativeness, which, in turn, positively influences its business performance. A meta-analysis of independent studies points in the same direction, attesting that overall market orientation as well as customer orientation, competitor orientation, and interfunctional coordination positively affect innovation consequences (Grinstein, 2008).

Media Industry and Startups

In the media industry, the environment is particularly turbulent (Achtenhagen, 2008; McKelvie \& Wiklund, 2008). Digitalization and technology lead to high uncertainty about the future of news and the need for innovation (Kaye \& Quinn, 2010; van Weezel, 2010). New ideas and ventures have emerged within traditional media companies (Achtenhagen, 2008; Hass, 2011) or formed as startups. Examples such as BuzzFeed, The Huffington Post, and Vox Media show that the latter can be very innovative and successful within a short period of time. However, there is little research on entrepreneurship and new businesses in the news media industry.

In recent decades, entrepreneurship has not been a concept that is closely identified with the media (Compaine \& Hoag, 2012). The vast majority of scholarly work in the field of media management has been conducted around large firms. Entrepreneurial behaviors of individuals as well as entrepreneurial activities and processes of startups are widely neglected (Achtenhagen, 2008; McKelvie \& Wiklund, 2008; Naldi \& Picard, 2012). Despite the limited number of publications, the field of research has a strong relevance to media management (Hang \& van Weezel, 2007).

Studies show that small organizational size does not imply small capabilities (Davis, Vladica, \& Berkowitz, 2008) and that firms of all shapes and sizes can be innovative (McKelvie \& Wiklund, 2008). Conversely, new firms tend to challenge established companies by providing radical innovations that change the market, and in some cases, they even create new industries. From a societal and industrial perspective, it is shown that new and young firms generate economic growth and the majority of new jobs (Audretsch, 1995; McKelvie \& Wiklund, 2008). In addition, Achtenhagen (2008, p. 138) argues that "media entrepreneurs play the role of change agents in society by ... engaging in a process of continuous innovation, adaption, and learning." According to
Compaine and Hoag (2012), a vibrant and innovative media sector is also important for democracy. Consequently, startups deserve closer attention to gain an in-depth understanding of the media industry as a whole (Achtenhagen, 2008; McKelvie \& Wiklund, 2008). Hang and van Weezel (2007) detect a growing demand for research in this field.

Applying Market-Orientation Theory to News

Startups

When investigating market orientation in the media, one must consider the unique characteristics of media products and services, which restrict the direct transfer of any theory to the field of media (Dogruel, 2014). Raviola and Hartmann (2009) emphasize the importance of adjusting business literature to the respective environment and news organizations in particular. First and foremost, media outlets have to serve audiences and advertisers at the same time (Wildman, 2006). The two-sided markets concept explains their business model (Anderson \& Gabszewicz, 2006; Rochet \& Tirole, 2006). One or several platforms enable interactions between end users. Changes in a first market always affect the second one, and vice versa. In this scenario, network effects are particularly important as they are two-sided as well (Eisenmann, Parker, \& Van Alstyne, 2006; Varian, Farrell, \& Shapiro, 2011). Accordingly, individuals and advertisers benefit from a news outlet's growing audience, and 
the audience benefits from the advertisements. The markets' relationships show in an increase in reader demand, which results in an increase in advertising rates. Meanwhile, an increase in advertising demand leads to a decrease in cover prices (Kaiser \& Wright, 2006). Of course, there are also other factors which could lead to increasing advertising rates and increasing advertising demand, such as the worth of certain target groups, the quality of audience metrics as well as brand positioning. Regarding competitors, Kind, Nilssen, and Sorgard (2009, p. 1112) find that "the scope for raising revenues from consumer payment is constrained by other media firms offering close substitutes" and that "a media firm's scope for raising revenues from ads, on the other hand, is constrained by how many competitors it faces."

This results in the need to adapt the market orientation model, which has been applied to the twosided market scenario by Sommer and Krebs (2016). Market-oriented media outlets generate, disseminate, and coordinately respond to market intelligence on audiences, advertisers, and competitors to be successful. As advertisers pay for access to audiences and audiences benefit from advertisements being informative and contributing to revenues, the audience market and the advertising market are connected. Depending on the media outlet's business model and the markets' importance for its incomes, one group of customers is potentially favored over the other. Au- diences' relationships to competitors are determined by the availability of substitutes and other players attempting to reach the same target group. The advertising market is also connected to the competition. While advertisers might find substitutes elsewhere, competitors aim for a share of the advertising market. Overall, market orientation should positively influence a media outlet's success.

Beam has contributed much to the field of market orientation in the media. His studies investigate its relationship to environmental uncertainty (Beam, 1996), journalistic values (Beam, 1998), success in terms of higher circulation and household penetration (Beam, 2001), and content differences (Beam, 2003). Throughout his research, which focuses on the audience market, he points out the differences between newspapers with a weak market orientation and those with a strong market orientation, such as senior editors from market-oriented newsrooms expressing less uncertainty about their outlet's environment and feeling more confident about adapting to changes in its environment (Beam, 2001). However, findings in Sommer and Krebs (2016) are contradictory: while dailies' reader orientation is positively correlated with success in terms of change of circulation, the opposite holds true for weeklies.

Market research in media practice also tends to focus on the audience side. Informal ways to collect information include private contacts, colleagues' re- ports, and readers' feedback (Weaver, Beam, Brownlee, Voakes, \& Wilhoit, 2007). While observations and experiments are rare, news outlets use tools such as surveys and focus groups quite frequently (Beam, 1995). In recent times, the analysis of online and social media data has attracted considerable attention (Anderson, 2011, 2013; Cherubi \& Nielsen, 2016; Christin, 2014; Dick, 2011; Graves \& Kelly, 2010; Lee, Lewis, \& Powers, 2014; Tandoc, 2014a, 2014b; $\mathrm{Vu}$, 2014; Westlund \& Lewis, 2014). Tandoc and Ferrucci (2014) investigate web analytics and find the adoption of such practices being further developed in market-oriented newsrooms. While journalists see advantages in these new opportunities to learn more about audiences, their preferences, and their liking of the news, they are also concerned about the integrity and values of journalism. This has resulted in a potential conflict between what the audience actually wants versus journalists' judgment of newsworthiness (MacGregor, 2007; Tandoc \& Thomas, 2014). However, at least on the journalism side, there appears to be a lack of systematization, especially in terms of how to use audience metrics (Usher, 2013).

Other studies have focused on advertisers and competitors. Habann (2010) identifies advertisers accepting a new media product as a success factor of media innovations. Wirtz, Perlz and Ulrich (2011) study the drivers of advertising sales and find that marketing competencies such as market observa- 
tion, identification of market opportunities, and utilization of market opportunities have a positive effect on advertising revenue. Compared with other players, media outlets have to offer an advantage to their customers to be successful (Bleis, 1996). Monitoring competitors also has a positive influence on a media innovation's success (Habann, 2010). Numerous studies focus on the influence of competition on content and advertising (e.g., Becker, Hollifield, Jacobsson, Jacobsson, \& Vlad, 2009; Coulson \& Lacy, 1996; Lacy, 1987; Shaver \& Lacy, 1999). Research also finds that media outlets respond to competition, for instance, through release strategies, product differentiation, and increasing expenditures (Krider \& Weinberg, 1998; Lacy \& Martin, 2004; Lee \& Han, 2006; Shrikhande, 2001). For dailies, a swift reaction to competitors' initiatives is positively related to success, while it is again the opposite for weeklies (Sommer \& Krebs, 2016).

In addition to the two-sided market, media products have characteristics, such as being experience goods, public goods, and cultural goods, that in combination make them different from non-media products (Chan-Olmsted, 2006; Craig, 2013; Doyle, 2013; Sommer, 2015). As news and journalism fulfill certain functions for society, market orientation in news media is often criticized (Cohen, 2002; McManus, 1994). Traditional news outlets such as The New York Times feel obligated to respect their standards

The Journal of Media Innovations 4.2 (2018),34-54 of journalistic judgment and high-quality reporting, while other news outlets are more prone to follow the market. Especially online, boundaries are less clear. Several studies have addressed conflicts between the editorial and the business perspective (Achtenhagen \& Raviola, 2009; Andersson \& Wiik, 2013; Gade, 2002; Nielsen, 2016; Raviola, 2012). Gade \& Raviola (2009) identify re-oriented professional values. Currah (2009) worries about news publishers fighting for clicks, consumer eyeballs, and advertising revenue, as it puts them in danger of becoming "digital windsocks” and losing journalisms' professional integrity. Customization of news raises concerns about eroding the social-cohesive role of mass media (Domingo, 2008). However, new competitors with a focus on technology, such as news aggregators, may not share such worries.

From reviewing the literature, it is possible to conclude that market orientation in the media is potentially different than that in other industries because of media outlets' need to address two markets and the media's importance for culture and society. Studies so far have focused on certain components of the market orientation model, while a comprehensive analysis of market orientation from a media management perspective is still missing.

Literature on entrepreneurship and startups in the media is particularly scarce. In a first exploratory study, McKelvie and Wiklund (2008) show that

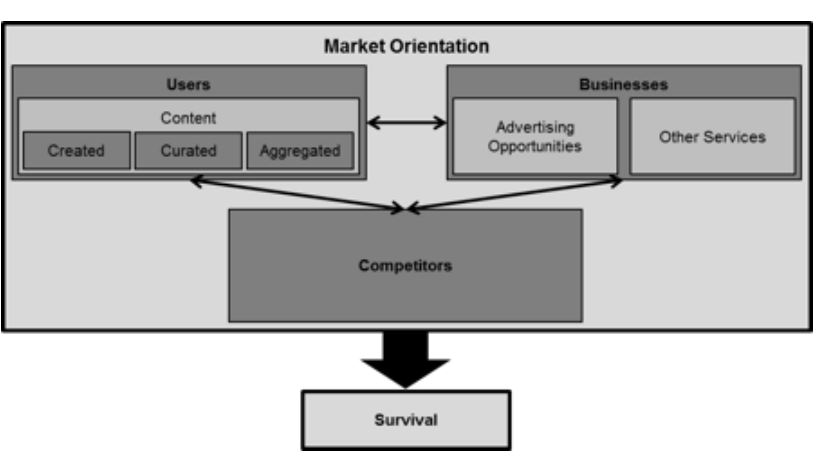

Figure 1: Market orientation of news startups

knowledge acquisition practices of new and young media outlets are the largest explanatory factors for both product and customer innovation. The authors argue that investing time and resources in both market-oriented and technology-oriented knowledge pays off in innovative output, which is particularly important for new venture performance. However, to date, the literature has not addressed how this knowledge of audiences, advertisers, and competitors is actually used (McKelvie \& Wiklund, 2006). In addition, the two-sided market concept and network effects have not been accounted for in sufficient detail. In a recent study, Bruno and Nielsen (2012) examine the performance of journalism startups that create, curate, and/or aggregate content. They highlight their diverse revenue streams and define success as survival, which leads to the need for specification of 
the market orientation model for news startups (see Figure 1). News startups have to generate, disseminate, and coordinately respond to market intelligence about (1) their users to whom they provide created, curated, and/or aggregated content; (2) businesses for which they offer advertising opportunities and other services; and (3) competitors. As a result, market orientation should positively influence their survival.

Therefore, the present study focuses on the processes regarding market orientation in news startups. As shown above, market orientation is potentially different in the media compared with other industries. To date, research has focused on traditional media outlets and the audience side. Moreover, little is known about the role of market orientation when starting a new media business from a media management perspective. Following the literature review, it is expected that market orientation will be particularly important for news startups and that startups will be more innovative and experimental in this area. This study aims to explore and analyze the practices and processes of market orientation in new and young media outlets. In addition, it will relate the findings to practices in traditional media outlets as described in the literature, which are potentially different because of their maturity, size, and journalistic values. These insights are valuable from an academic perspective, because of the contribution towards a holistic under-

The Journal of Media Innovations 4.2 (2018),34-54 standing of market orientation theory in a specific industry. For media entrepreneurs, the results provide evidence about the processes and the importance of market orientation when starting a media business.

\section{METHOD}

Case Study and Case Selection

To investigate market orientation of news startups, this study follows a case study approach, which offers an in-depth look at what roles users, businesses, and competitors play for new and young media outlets. Case studies are well established in media management research (Hollifield \& Coffey, 2006; von Rimscha \& Sommer, 2016). They combine different types of data collection such as desk research and interviews. Access to several startups founded in recent years was gained through the Tow-Knight Center for Entrepreneurial Journalism in New York. Following Yin's (2009) recommendation to analyze more than one case to strengthen the findings, four startups were selected (see Table 1).

In selecting the startups, the criteria balance, variety, and opportunity to learn were considered (Stake, 1995). All of the startups offer news to their users and they were in similar stages at the time of this study, which is the foundation of a balanced sample. However, they differ in terms of content (creation, curation, and/or aggregation), target group (users and/ or businesses), and revenue stream(s) (subscriptions, advertising, and/or other services). Hence, the four selected cases allow this study to cover a variety of news startups. As opposed to examining typical cases, this approach provides an opportunity to identify a wider range of practices and increase generalizability (Flyvbjerg, 2006). Consequently, the goal is not to compare cases, but to formulate a cross-case synthesis; therefore, they were studied within their contexts (Yin, 2009).

Ada is a technology news service for women, funded through advertising and syndication deals with traditional media. Go Baller aggregates sports content for sports fans (funded through advertising) and offers sports brands a platform where their content from all over the web is put in one place in a software as a service (SaaS) model. Informerly provides personalized industry news through a newsletter and a subscription-based mobile app. Upstrt is a free email newsletter, delivering the most relevant news on the Internet of Things. These four startups have agreed to participate in the present study.

Implementation

The data for this study was collected through multiple sources. First, the websites, social media channels, and mobile services of the selected media startups were analyzed to gain an understanding of the basic idea as well as the contents and services offered. Notes were taken in a database to keep track 
Table 1.

\begin{tabular}{|c|c|c|c|c|c|c|}
\hline Startup (founded) & Country & Idea & Product/Service & Target Group & Revenue & User Base \\
\hline Ada (2014) & Brazil & $\begin{array}{l}\text { Technology and digital } \\
\text { culture news for women }\end{array}$ & Creation and curation & $\begin{array}{l}\text { Users and } \\
\text { businesses }\end{array}$ & $\begin{array}{l}\text { Advertising } \\
\text { syndication }\end{array}$ & Thousands \\
\hline Go Baller (2014) & United States & $\begin{array}{l}\text { Social discovery app for } \\
\text { sports fans }\end{array}$ & Aggregation & $\begin{array}{l}\text { Users and } \\
\text { businesses }\end{array}$ & $\begin{array}{l}\text { Advertising, } \\
\text { SaaS }\end{array}$ & Pre-launch \\
\hline Informerly (2013) & United States & $\begin{array}{l}\text { Industry news personalized } \\
\text { for your inbox }\end{array}$ & $\begin{array}{l}\text { Semi-automated } \\
\text { aggregation }\end{array}$ & Users & Subscriptions & Thousands \\
\hline Upstrt (2014) & United States & $\begin{array}{l}\text { Free email newsletter on } \\
\text { Internet of Things news }\end{array}$ & $\begin{array}{l}\text { Curation and manual } \\
\text { aggregation }\end{array}$ & $\begin{array}{l}\text { Users and } \\
\text { businesses }\end{array}$ & Advertising & Dozens \\
\hline
\end{tabular}

of these characteristics. Second, additional information was examined, such as videos and news articles, to learn more about the startups' development and background. Again, notes were collected in a database to understand potential changes over time. For the first two steps, idea, product/service, target group, revenue, user base, and other were the main categories. Third, in November and December 2014, semi-structured, in-depth interviews with the start-

The Journal of Media Innovations 4.2 (2018),34-54 ups' founders were conducted. The interview guides were developed from the literature on market orientation and news startups, as summarized earlier. They included questions on the original idea for the startup and its development as well as a focus on the roles of users, businesses, and competitors in its processes. Interviewees were treated as "informants." They had to describe "how things are," rather than provide interpretations of their startup regarding the research question. The interviews were informal in nature and lasted 30 to 45 minutes each. They were recorded and subsequently transcribed. Fourth, internal documents and information obtained during the interviews or after were studied, such as surveys and additional background facts that illustrated the interviewees' statements. The different types of data provided different kinds of insights. The website and other services gave an impression of the startups' of- 
ferings as well as their positioning. The videos and news articles allowed following the development of the startup over a longer period of time. Furthermore, the first two steps generated valuable background information for conducting the interviews. The interviews provided specific information for the research question regarding market orientation of news startups. Additional documents provided an even deeper insight into their practices and processes. They also allowed evaluation of the statements of the interviewees. Therefore, a complementary mixture of contextual and specific data, as well as objective and subjective information was collected.

For the analysis, a deductive approach was employed to support the comparability of the multiplecase study (Johansson, Ellonen, \& Jantunen, 2012). The present study also relied on theoretical propositions and cross-case synthesis, as recommended by Yin (2009). The literature review and the interview guidelines served as the framework for coding transcripts and all other material using MAXQDA software (Simons, 2009), while remaining open for additional themes. Subsequently, emerging patterns across cases as well as differences between them were identified. Throughout the analysis, the original material was consulted multiple times to further strengthen the findings. Finally, the components of market orientation, users, businesses, and competitors, were rated high, medium, or low for every start- up, depending on the number of tools used as well as the level of professionalism associated with them.

When designing and conducting the case studies, quality criteria were considered, as discussed in the literature (Yin, 2009). To enhance reliability, the same four steps of data collection were followed for each case, as described above. Additional notes were kept alongside all material in the case database in MAXQDA. To increase construct validity, multiple sources of evidence were used, such as interviews, videos, and secondary data. Internal validity was enhanced through alternative methods of analyzing the data such as cross-case pattern matching and explanation building. Finally, external validity was supported by examining four cases (replication logic) and building the protocols for data collection and analysis based on a thorough literature review.

\section{RESULTS}

Overall Market Orientation

The startups investigated in this study thoughtfully chose the market that they wanted to enter. In the course of their market research, the founders evaluated the volume and potential for future growth. Opportunities on the users' as well as the businesses' side were considered, e.g.:
Ada will be the bridge between the tech industry and the female consumer market. I think with our content we'll build a community of women who are interested in this theme and that would be highly valuable for advertisers. (Ada).

Go Baller started out with the idea of an app for sports fans which aggregates content and makes money from advertisers before providing additional services to businesses (SaaS). Selling advertisements in a special interest space was also the revenue model for the website Ehip News, which led to the development of Informerly. The idea for Upstrt was based on the market potential of the audience and the advertiser side around the Internet of Things and a lack of competition. In the following, user orientation, business orientation, and competitor orientation at Ada, Go Baller, Informerly, and Upstrt will be thoroughly examined.

\section{User Orientation}

A shared characteristic of the startups in this study is that they placed users and their needs first. After identifying a problem, the focus was on solving it and providing the best service: "The entire core of our business is trying to answer what the users want and making their life easier" (Informerly). Go Baller was very clear about heading in the direction that the users pointed out to them. This holds true for the con- 
tent as well as the design of the product: "We want to do as much as we can to make it aligned with exactly what they want and then just stick to our core values in the process" (Go Baller).

To be able to do so, startups conduct market research. They look at information that is already available, such as industry reports; however, they also start their own investigations. This is done informally as well as in a more organized and planned manner. The founders talked to friends and colleagues about their ideas to obtain feedback as early as possible. Having a good network is extremely important in this stage. Ada had a set of questions to collect information about women, their habits, and their interest in technology news. Interviews were targeted towards "Everybody who would talk to me, just to have a sense of what that group needed.” For Informerly, direct contact in person and over the phone was important: “There's so many tools now that help entrepreneurs try to monitor stuff without talking to the end-user, but just getting out and talking to people was the key in all of that." The startup made sure to talk to highly engaged users throughout the process of further developing the product and based its decisions on their findings such as opting for a mobile app instead of a website. The startups also conducted surveys. For instance, Go Baller asked sports fans about their preferred sources for sports content on social media. The results helped them to optimize the service and fulfill users' needs even more. The startups' findings would also influence decisions and future directions of the business, by either providing support for a chosen route or changing the founders' perspective. Informerly inquired about its users' preferred mobile operating systems when developing the mobile app. However, getting to know the users' needs is not only important for the product - it can also ease the relationship between co-founders when shifting the focus from individual beliefs towards market-oriented research:

One of the mistakes we made early, the worst thing cofounders can do, is sit in their room and try to debate what they want in a product, or what they think is the best product. ... And then we realized everything should just be based on 50 people said this, or 70 people said this. It makes everything less personal between cofounders, which is important. (Informerly)

In addition to market research, startups try to collect feedback from and engage with their users on an ongoing basis. Prototypes are tested early and demonstrated in front of different audiences: "We try to incorporate every type of feedback we can get, the more feedback the better" (Go Baller). Ada's founder uses social media as a tool and it is very curious about its readers' opinions:
If someone tells me 'I love that,' I'm going to grill them, 'What did you like about it? What didn't you like about it? What do you think we could improve?' I use that. It's not systematically in that sense, I don't have a methodology for it.

In the course of these interactions, startups are open to fulfilling their users' requests, which could result in an article on a specific topic (Ada) or in adjusting the personalized settings for the newsletter (Informerly). Despite being mostly informal, it helps build relationships with the users: "Even as a writer, you try to always tell the story the right way and engage, I think engagement is the key word" (Go Baller). Having an engaged user base is equivalent to loyalty and trust. The community evolving around the service is crucial for startups.

However, having an engaged and loyal community is not the only measure of success. Startups also have to keep track of quantitative metrics. For Ada, unique visitors are important. In addition to the total traffic, the startup looks at how individual articles are doing to focus on popular topics. However, newsworthiness is also always a criterion. Considering the interests of the audience is important for Upstrt as well:

I don't have a methodology yet. It's kind of informally, looking at results as it goes along and seeing what resonates with people and keeping it in my own head. If it 
gets to a larger number, I think I'll probably try to apply some actual analytics to it.

Go Baller focuses attention on the entire range of metrics. The startup looks at app downloads compared to how many users come back and spend time on the app, as well as time spent personalizing the app like choosing a favorite team, players, and events. For Informerly, analytics are an integral part of the service since what the users click on influences the personalized newsfeed: "We think a media company should know every single person, which is completely opposite of how it works right now." Consequently, they decided against joining the race for unique visitors: "The value we have is the list of people. Playing the pure traffic game, we realized, is not where the world's going to end up" (Informerly). In addition to helping with meeting users' needs and improving the service, user data is also important for the advertising market.

\section{Business Orientation}

The founders thought about the advertising side of a typical media business early in the process of developing their startup. Upstrt turned out to be an email newsletter rather than a website since the format delivers actionable statistics:
Who's clicked on what, what time the email was opened and things like that. I think that's going to be eventually more compelling to advertisers, which is one of the reasons why I went down that road.

However, startups put less effort into market research in this field. They also pointed out that they have a good understanding of the advertising market because of their experience in other media outlets. The founders of Ada and Informerly exploited contacts in their professional network to collect different opinions. The startups used their findings to make decisions and adjust the direction of the business. For instance, Informerly's founder, focusing on a subscription model instead of advertising, stated: "It was in those conversations, realizing that's a whole different thing that distracts from what we are trying to do."

One of the reasons for less market research on the advertising side can be found in the perceived superior importance of the user in the early stages. Startups feel like they need to build a user base first, before thinking about advertising in more detail: "I haven't attempted to sell ads on the email because I haven't reached the subscriber number I feel like I need to present a case for something that would be interesting" (Upstrt). The same holds true for Ada, to which advertisers recommended growing its audience first.
The second reason for neglecting the advertising market is a focus on alternative revenue streams. Ada successfully creates content for other media outlets, which generates income as well as traffic for the website. Go Baller aims to offer sports brands a platform that they can market to their fans. Also in this business-to-business field, market research and listening to potential clients' feedback is crucial:

I've been talking to different editors from sports media outlets who are interested in that type of product. Once we launch and get ourselves in the hands of clients, we'll probably do a couple pilot runs and then see how it goes and figure out pricing models. (Go Baller).

This platform will allow sports brands to collect valuable data about the users to monetize social media. In developing the business further, Go Baller partners with clients to learn about their needs and make improvements in fulfilling them.

For Upstrt, traditional media outlets are too focused on advertising and they fail to explore alternative revenue streams:

It is not really thought about what the needs of the reader are. [They think] trying to create content that people are going to be willing to advertise on is more important than creating content that people would find useful. 
Regarding new ideas in advertising and alternative revenues, another consideration for startups is what their competition is doing.

Competitor Orientation

The startups investigated in this study have a very broad understanding of competition:

We have competitors in all different landscapes. Any place where people go to get sports, that's your competition. But we really just have to focus on being the best that we can be and capitalizing on all their weaknesses and learning from that along the way. (Go Baller)

For Ada, the competition is other tech news, whether it is traditional media's reporting or bloggers writing about personal experiences. In general, knowledge about the market and the competition's strengths and weaknesses is seen as important:

The more you learn about the market the more you can learn about everything, the more advice you get, the more feedback you get, on everything from business to product, realizing what is Go Baller's place in the market, how do we fit in. (Go Baller)

For Informerly, being in New York was crucial and it allowed the startup to study the competition "obsessively." Moreover, it benefited from sharing office space with Reddit and being able to learn from others' experiences as well as its own. Following the experience with the predecessor Ehip News, Informerly chose a different path than the highly competitive fight for unique visitors. Informerly also monitors industry trends on an ongoing basis: "I am already sifting through tons of media news anyways. That's how it is easy to keep up-to-date with what's going on." For Go Baller's founder, knowing about mobile apps is essential:

I have every app known to mankind that could be some sort of competitor or ally or partner. I have every news app, every news curation, personalization, aggregation app on my phone. I love reading about and testing out new products when it comes to mobile apps.

Ada's and Upstrt's research activities on competitors are rather informal and not standardized. More specifically, they monitor news, check RSS feeds, and follow influencers' social media accounts. However, this is primarily done to have an overview of what the most important topics are at the moment. Staying "up-to-date" with the changes in the marketplace and the latest trends is a by-product. The lack of competition around the Internet of Things, identified by Upstrt when developing the startup, proved to be more difficult than expected:
What I'm starting to learn is that, if there is not something out there existing in your niche, there might be a reason for that. In a lot of times it is better to go with some competition because it means that somebody's making money in that realm.

Facing significant competition in sports news, Go Baller moved towards offering services to businesses such as aggregating content for sports brands as well as giving insights and analytics to their clients. It followed a simple principle: "Why try to compete with them directly when I could partner with all of them, potentially, and give them our social media curation services" (Go Baller). This shows how flexible startups react, not only to the needs of users and businesses but also to competitors in the market.

\section{DISCUSSION}

The news startups under study show characteristics of market orientation, as identified in the literature: generating, disseminating, and coordinately responding to market intelligence (Kohli \& Jaworski, 1990). They think about different markets and their connections from the beginning. They explore the user side, the advertising market, and the competition, which is similar to traditional media outlets' market orientation model. Moreover, they look at other revenue streams and experiment with different business models in the early stages. In these processes, net- 
work effects are extremely important. Consequently, the media startups in this study decided to focus on one market (users) or serve two groups of customers (users and businesses). Their curiosity about these options and their willingness to take the risk to follow unconventional paths shows that market orientation does not necessarily lead to "me-too" products and services, but it can foster innovation (Wren et al., 2000). However, in the process of further developing the business in a two-sided market, startups prioritize certain markets and place different emphasis on users, businesses, and competitors.

Most of the attention is dedicated to users, where network effects are most important. Their needs are put first to offer the best product possible. Startups conduct market research both informally and formally, which is similar to traditional media outlets (Sommer \& Krebs, 2016). They not only look at industry reports and various statistics but also launch their own investigations. The most popular approaches include talking to colleagues, business contacts, and users in person or on the phone, and conducting surveys. The knowledge acquired about users' needs and preferences is shared across the startup and discussed in the decision-making processes (Narver \& Slater, 1990). Particularly important is quantitative data generated by the service itself, for instance, the clicks on links. Startups look at as many metrics as possible to learn about user behavior to improve their products and

The Journal of Media Innovations 4.2 (2018),34-54 services. The similarity to traditional media lies in the lack of systematization regarding how to use the data (Usher, 2013). However, while at traditional media outlets reservations to follow the data are common (MacGregor, 2007; Tandoc \& Thomas, 2014), the startups are far more open to adjust to their findings and they are less concerned about journalistic values and media's implications for society.

The advertising market is explored less systematically. Startups build on their experience in other media outlets and talk to contacts in their professional network to collect information about advertisers' interests. This enables them to monitor the market and identify opportunities (Wirtz et al., 2011). Despite thinking about what could be valuable to advertisers, startups do not put their needs first. This differs from some traditional media outlets. As a consequence, startups also explore alternative revenue streams in more detail (Bruno \& Nielsen, 2012; Cook \& Sirkkunen, 2013). These include partnerships with traditional media outlets as well as offering services for other organizations. Diversification has also been a focus of media giants such as Bertelsmann and The Walt Disney Company (Dubini \& Raviola, 2005). Startups reach out to professional contacts in their network to learn about the needs of their businesses, and they partner with them in further developing the service. This gives them the opportunity to gain even deeper insights into the market and collect inside knowledge, which would not be accessible otherwise. Similar to the approach on the user side, startups are more than willing to fulfill their clients' demands and tailor the service to their needs. This adds to the literature on the relationship between editorial and business staff such as the re-orientation of professional values (Gade \& Raviola, 2009).

In terms of competition, the startups under study have a very broad understanding. They monitor industry trends on an ongoing basis and attempt to learn as much as possible about their environment, which is also important for traditional media outlets (Habann, 2010). While studying the competition is a by-product for some, other startups analyze the strengths and weaknesses of competitors to derive decisions for the direction of their business and their positioning in the market (Narver \& Slater, 1990; Slater \& Narver, 1995). This is achieved by following news, feeds, and social media as well as personal contacts, which is rather informal. In comparison, traditional media outlets tend to have a narrower understanding of competition (Sommer \& von Rimscha, 2014).

Table 2 summarizes the four cases regarding the three components of market orientation, which are defined in Figure 1. In addition, there is a focus on whether the startups under investigation pivoted from their original idea ("Changes") and what progress they were making ("Survival”). Overall, Infor- 
Table 2:

\begin{tabular}{|c|c|c|c|c|c|}
\hline \multirow[b]{2}{*}{ Startup } & \multicolumn{3}{|c|}{ Market Orientation } & \multirow[b]{2}{*}{ Changes } & \multirow[b]{2}{*}{ Survival } \\
\hline & Users & Businesses & Competitors & & \\
\hline Ada (2014) & Medium & Medium & Low & None & Stagnation \\
\hline Go Baller (2014) & High & High & High & $\begin{array}{l}\text { From app to software as a } \\
\text { service }\end{array}$ & $\begin{array}{l}\text { Secured funding and } \\
\text { launched app }\end{array}$ \\
\hline Informerly (2013) & High & Medium & High & $\begin{array}{l}\text { From website to newsletter } \\
\text { to subscription service }\end{array}$ & $\begin{array}{l}\text { Secured funding and } \\
\text { launched subscription } \\
\text { service }\end{array}$ \\
\hline Upstrt (2014) & Low & Low & Low & None & $\begin{array}{l}\text { Newsletter } \\
\text { on hold }\end{array}$ \\
\hline
\end{tabular}

merly and Go Baller placed most effort into learning about and adjusting to users, businesses, and competitors, as summarized in Table 2. Consequently, the founders significantly adjusted their original idea. In line with the market orientation model for media startups (see Figure 1), these two startups were able to raise funding from investors and they are most likely to survive. They also followed unconventional paths and experimented with business models which corre- sponds with market orientation fostering innovation (Atuahene-Gima, 1996; Ordanini \& Maglio, 2009). Ada and Upstrt, however, placed fewer resources into market orientation. Both startups followed an informal approach and adjusted less to their findings. In doing so, they did not see the expected growth and their survival is uncertain.

These results contribute to the research about market orientation theory in the media. The present study shows that news startups do not consider journalistic values and media's impact on society as much as traditional media. Howat (2000) noted that old boundaries do not have the same meaning in the online world. A conflict between editorial and business described by Achtenhagen and Raviola (2009) was not detected. Consequently, in this respect, differences between the media business and other industries are less significant than pointed out in the literature. What makes media special is the two-sided market (Wildman, 2006). Accordingly, market orientation of news startups is characterized by generating, disseminating, and coordinately responding to market intelligence about users, businesses, and competitors on an ongoing basis. In doing so, it is important to consider network effects and to prioritize markets based on the findings to survive and succeed.

Regarding market orientation theory and innovation in the media industry, the present study finds that generating market intelligence and responding to the findings does not necessarily lead to "me-too" products. For news startups, the opposite seems to be true; that is, the more they learn about their environment, the better they are at exploring new paths and finding their distinct niche. Therefore, market orientation is important for developing and improving new media products and services. This positive influence of market orientation on innovation is in line with a meta-analysis conducted by Grinstein (2008). The 
results also add to the literature on processes of innovation in online journalism (Mitchelstein \& Boczkowski, 2009).

For market orientation, these findings indicate that there is no universal theory, similar to Raviola and Hartmann's emphasizing the importance of contextualizing business literature to the specific environment (2009). The components of the concept differ by industry and have to be adjusted depending on the context. However, there will be similarities, for example between companies in two-sided markets. Regarding market orientation in times of uncertainty, such as starting a new business, the present study illustrates market-oriented companies' superior performance, based on a better understanding of groups of customers and competitors which is in line with Wren et al. (2000). This finding is particularly important for entrepreneurs thinking about market orientations' importance and evaluating different approaches.

\section{LIMITATIONS AND FURTHER RESEARCH}

This exploratory study is based on four cases of early stage news startups. It must be kept in mind that they received training through the Tow-Knight Center for Entrepreneurial Journalism. Consequently, generalizability to the media industry as a whole is limited. In particular, larger media outlets in which processes and responsibilities are more differentiated may sub- stantially differ. For instance, they could have more resources for market research, but at the same time, they could be less willing or able to adapt to their findings. Thus, future studies need to examine these potential differences between smaller and larger media outlets, not only from a journalism point of view but also from a media management perspective. It would also be valuable to follow media outlets over an even longer period of time and analyze their market orientation in relation to their success. This approach would allow an investigation of the influence of market orientation in different stages of a startup's maturity as well as on its development and innovativeness. Finally, market orientation needs to be related to other success factors to understand its relative importance.

\section{CONCLUSION}

The four case studies show that news startups in their early stages generate market intelligence in various ways and, in doing so, prioritize markets. Their investigation of the user side is most comprehensive. They use qualitative and quantitative methods, such as interviews and surveys, to learn about users' needs and behaviors. In the advertising market, startups follow a less formal approach, mainly relying on their personal experiences and conversations. However, they still explore alternative revenue streams, interview potential clients, and partner with them to meet their needs. Startups also analyze the strengths and weaknesses of their competitors as well as monitor news and exchange experiences with other startups to stay up-to-date with current trends and the competition.

The collected knowledge is distributed across each startup and discussed in the decision-making processes. More specifically, it is used on different levels: specific metrics for minor adjustments such as the design; quantitative and qualitative data for central questions such as which content to focus on; and qualitative information when choosing a direction for the business such as the dependence on advertising. The cases show how open and flexible startups are to adjust to their findings. This is in line with previous research pointing out new firms being particularly attentive to their business environments (McKelvie \& Wiklund, 2008). Our results also suggest that startups that are more market-oriented are more likely to survive.

In terms of market orientation theory in the media industry, the study indicates the importance to taking the industry's specific environment into consideration (Raviola \& Hartmann, 2009), such as the twosided market. This translates to market orientation being characterized by generating, disseminating, and coordinately responding to market intelligence about users, businesses, and competitors on an ongoing basis. In doing so, prioritizing groups of customers and competitors based on the findings is crucial. 
For entrepreneurs in the media industry, the present study highlights that generating market intelligence and responding to the findings is important for survival and success.

\section{Christoph Sommer}

University of Zurich

ch.sommer@ipmz.uzh.ch

\section{REFERENCES}

Achtenhagen, L. (2008). Understanding entrepreneurship in traditional media. Journal of Media Business Studies, 5(1), 123-142.

Achtenhagen, L., \& Raviola, E. (2009): Balancing tensions during convergence: Duality management in a newspaper company. International Journal on Media Management, 11(1), 32-41. DOI: http://dx.doi.org/ 10.1080/14241270802518505

Anderson, C. W. (2011). Between creative and quantified audiences: Web metrics and changing patterns of newswork in local US newsrooms. Journalism, 12(5), 550-566. DOI: http://dx.doi. org/10.1177/1464884911402451

Anderson, C. W. (2013). Rebuilding the news: Metropolitan journalism in the digital age. Philadelphia: Temple University Press.

Anderson, S. P., \& Gabszewicz, J. J. (2006). The media and advertising: A tale of two-sided markets. In V. A. Ginsburgh \& C. D. Throsby (Eds.), Handbooks in economics: Vol. 25. Handbook of the economics of art and culture (pp. 567-614). Amsterdam \& Oxford, UK: North-Holland.

Andersson, U., \& Wiik, J. (2013): Journalism meets management. Journalism Practice, 7(6), 705-719. DOI http://dx.doi.org/ 10.1080/17512786.2013.790612
Atuahene-Gima, K. (1996). Market orientation and innovation. Journal of Business Research, 35(2), 93-103. DOI: http://dx.doi.org/10.1016/o148-2963(95)ooo518

Audretsch, D. B. (1995). Innovation and industry evolution. Cambridge, MA: MIT Press.

Baumgarth, C. (2009). Brand orientation of museums: Model and empirical results. International Journal of Arts Management, 11(3), 30-45.

Beam, R. A. (1995). How newspapers use readership research. Newspaper Research Journal, 16(2), 28-38.

Beam, R. A. (1996). How perceived environmental uncertainty influences the marketing orientation of U.S. daily newspapers. Journalism \& Mass Communication Quarterly, 73(2), 285-303. DOI: http://dx.doi. org/10.1177/107769909607300202

Beam, R. A. (1998). What it means to be a market-oriented newspaper. Newspaper Research Journal, 19(3), $2-20$

Beam, R. A. (2001). Does it pay to be a market-oriented daily newspaper? Journalism \& Mass Communication Quarterly, 78(3), 466-483. DOI: http://dx.doi. org/10.1177/107769900107800305

Beam, R. A. (2003). Content differences between daily newspapers with strong and weak market orientations. Journalism \& Mass Communication Quarterly, 8o(2), 368-390. DOI: http://dx.doi. org/10.1177/107769900308000209 
Becker, L. B., Hollifield, C. A., Jacobsson, A., Jacobsson, E.-M., \& Vlad, T. (2009). Is more always better? Examining the adverse effects of competition on media performance. Journalism Studies, 1O(3), 368-385. DOI: http://dx.doi.org/10.108o/14616700802636219

Bleis, T. (1996). Erfolgsfaktoren neuer Zeitschriften: Empirische betriebswirtschaftliche Untersuchung zur Entwicklung und Markteinführung von Publikumstiteln. Zugleich Dissertation an der Universität München, 1996. Medien Skripten: Vol. 27. München: Reinhard Fischer.

Boczkowski, P. J. (2004): Digitizing the News: Innovation in Online Newspapers. Cambridge: MIT Press.

Brïdson, K., \& Evans, J. (2004). The secret to a fashion advantage is brand orientation. International Journal of Retail \& Distribution Management, 32(8), 403-411. DOI: http://dx.doi.org/10.1108/o9590550410546223 Bruno, N., \& Nielsen, R. K. (2012). Survival is success: Journalistic online start-ups in Western Europe. RISJ challenges. Oxford: Reuters Institute for the Study of Journalism. Retrieved from https://reutersinstitute. politics.ox.ac.uk/publication/survival-success

Cadogan, J. W., \& Diamantopoulos, A. (1995). Narver and Slater, Kohli and Jaworski and the market orientation construct: Integration and internationalization. Journal of Strategic Marketing, 3(1), 41-6o. DOI: http:// dx.doi.org/10.1080/09652549500000003
Chan-Olmsted, S. M. (2006). Issues in strategic management. In A. B. Albarran, S. M. Chan-Olmsted, \& M. O. Wirth (Eds.), Handbook of media management and economics (pp. 161-180). Mahwah, NJ: Lawrence Erlbaum.

Cherubini, F., \& Nielsen, R. K. (2016): Editorial analytics: How news media are developing and using audience data and metrics. Digital News Project. Oxford: Reuters Institute for the Study of Journalism.

Christin, A. (2014). Clicks or Pulitzers? Web journalists and their work in the United States and France (Dissertation). Princeton University.

Cohen, E. L. (2002). Online journalism as market-driven journalism. Journal of Broadcasting \& Electronic Media, 46(4), 532-548. DOI: http://dx.doi.org/10.1207/ s15506878jobem4604_3

Compaine, B., \& Hoag, A. (2012). Factors supporting and hindering new entry in media markets: A study of media entrepreneurs. The International Journal on Media Management, 14(1), 27-49. DOI: http://dx.doi. org/10.1080/14241277.2011.627520

Cook, C., \& Sirkkunen, E. (2013). What's in a niche? Exploring the business model of online journalism. Journal of Media Business Studies, 10(4), 63-82.

Coulson, D. C., \& Lacy, S. (1996). Journalists' perceptions of how newspaper and broadcast news competition affects newspaper content. Journalism \& Mass Communication Quarterly, 73(2), 354-363.
Craig, C. S. (2013). Creating cultural products: Cities, context and technology. City, Culture and Society, 4(4), 195-202. DOI: http://dx.doi.org/10.1016/j. ccs.2013.06.002

Currah, A. (2009). What's happening to our news: An investigation into the likely impact of the digital revolution on the economics of news publishing in the UK. RISJ challenges. Oxford: Reuters Institute for the Study of Journalism, University of Oxford. Retrieved from https://reutersinstitute.politics.ox.ac.uk/ fileadmin/documents/Publications/What_s_Happening_to_Our_News.pdf

Danneels, E. (2002). The dynamics of product innovation and firm competences. Strategic Management Journal, 23(12), 1095-1121. DOI: http://dx.doi. org/10.1002/smj.275

Davis, C. H., Vladica, F., \& Berkowitz, I. (2008). Business capabilities of small entrepreneurial media firms: Independent production of children's television in Canada. Journal of Media Business Studies, 5(1), 9-39.

Day, G. S. (1994). The capabilities of market-driven organizations. Journal of Marketing, 58(4), 37-52. DOI: http://dx.doi.org/10.2307/1251915

Dick, M. (2011). Search engine optimisation in UK news production. Journalism Practice, 5(4), 462-477. DOI: http://dx.doi.org/10.1080/17512786.2010.551020 
Dogruel, L. (2014). What is so special about media innovations? A characterization of the field. The Journal of Media Innovations, 1(1), 52-69. DOI: http://dx.doi. org/10.5617/jmi.v1i1.665

Domingo, D. (2008). Interactivity in the daily routines of online newsrooms: Dealing with an uncomfortable myth. Journal of Computer-Mediated Communication, 13(3), 680-704. DOI: http://dx.doi.org/10.1111/ j.1083-6101.2008.00415.x

Doyle, G. (2013). Understanding media economics $\left(2^{\text {nd }}\right.$ ed.). Los Angeles: Sage.

Dubini, P., \& Raviola, E. (2005, July). Emerging business models in content industries. In Proceedings of the 8th International Conference on Arts \& Cultural Management, Montreal. Retrieved from https://www. researchgate.net/publication/228399724

Eisenmann, T. R., Parker, G., \& Van Alstyne, Marshall W. (2006). Strategies for two-sided markets. Harvard Business Review, 84(10), 92-102.

Flyvbjerg, B. (2006). Five misunderstandings about casestudy research. Qualitative Inquiry, 12(2), 219-245. DOI: http://dx.doi.org/10.1177/1077800405284363

Gade, P. (2002): Managing change: Editors' attitudes toward integrating marketing journalism. Newspaper Research Journal, 23(2/3), 148-153.
Gade, P., \& Raviola, E. (2009): Integration of news and news of integration: A structural perspective on news media changes. Journal of Media Business Studies, 6(1), 87-111, DOI: http://dx.doi.org/ 10.1080/16522354.2009.11073480

Graves, L., \& Kelly, J. (2010). Confusion Online: Faulty metrics and the future of digital journalism. Retrieved from Tow Center for Digital Journalism website: http://www.journalism.columbia.edu/system/documents/345/original/online_metrics_report.pdf

Grinstein, A. (2008). The effect of market orientation and its components on innovation consequences: A metaanalysis. Journal of the Academy of Marketing Science, 36(2), 166-173. DOI: http://dx.doi.org/10.1007/ s11747-007-0053-1

Habann, F. (2010). Erfolgsfaktoren von Medieninnovationen: Eine kausalanalytische empirische Untersuchung. Baden-Baden: Nomos.

Han, J. K., Namwoon Kim, \& Srivastava, R. K. (1998). Market orientation and organizational performance: Is innovation a missing link? Journal of Marketing, 62(4), 30-45. DOI: http://dx.doi. org/10.2307/1252285

Hang, M., \& van Weezel, A. (2007). Media and entrepreneurship: What do we know and where should we go? Journal of Media Business Studies, 4(1), 51-70.
Hass, B. H. (2011). Intrapreneurship and corporate venturing in the media business: A theoretical framework and examples from the German publishing industry. Journal of Media Business Studies, 8(1), 47-68.

Hollifield, C. A., \& Coffey, A. J. (2006). Qualitative research in media management and economics. In A. B. Albarran, S. M. Chan-Olmsted, \& M. O. Wirth (Eds.), Handbook of media management and economics (pp. 573-60o). Mahwah, NJ: Lawrence Erlbaum

Homburg, C., \& Pflesser, C. (2000). A multiple-layer model of market-oriented organizational culture: Measurement issues and performance outcomes. Journal of Marketing Research, 37(4), 449-462. DOI: http:// dx.doi.org/10.1509/jmkr.37.4.449.18786

Hong, J., Song, T. H., \& Yoo, S. (2013). Paths to success: How do market orientation and entrepreneurship orientation produce new product success? Journal of Product Innovation Management, 3o(1), 44-55. DOI: http://dx.doi.org/10.1111/j.1540-5885.2012.00985.x

Howat, K. J. (2000). Start-up of online ventures from corporate base and from point zero. Publishing Research Quarterly, 16(2), 6-13.

Jaworski, B. J., \& Kohli, A. K. (1993). Market orientation: Antecedents and consequences. Journal of Marketing, 57(3), 53-70. DOI: http://dx.doi.org/10.2307/1251854 
Johansson, A., Ellonen, H.-K., \& Jantunen, A. (2012). Magazine publishers embracing new media: Exploring their capabilities and decision making logic. Journal of Media Business Studies, 9(2), 97-114.

Kaiser, U., \& Wright, J. (2006). Price structure in twosided markets: Evidence from the magazine industry. International Journal of Industrial Organization, 24(1), 1-28. DOI: http://dx.doi.org/10.1016/j.ijindorg.2005.06.002

Kaye, J., \& Quinn, S. (2010). Funding journalism in the digital age: Business models, strategies, issues and trends. New York: Lang.

Kind, H. J., Nilssen, T., \& Sorgard, L. (2009). Business models for media firms: Does competition matter for how they raise revenue? Marketing Science, 28(6), 1112-1128. DOI: http://dx.doi.org/10.1287/ mksc.1090.0514

Kohli, A. K., \& Jaworski, B. J. (1990). Market orientation: The construct, research propositions, and managerial implications. Journal of Marketing, 54(2), 1-18. DOI: http://dx.doi.org/10.2307/1251866

Krider, R. E., \& Weinberg, C. B. (1998). Competitive dynamics and the introduction of new products: The motion picture timing game. Journal of Marketing Research, 35(1), 1-15.
Lacy, S. (1987). The effects of intracity competition on daily newspaper content. Journalism Quarterly, 64, 281-290. DOI: http://dx.doi. org/10.1177/107769908706400201

Lacy, S., \& Martin, H. J. (2004). Competition, circulation and advertising. Newspaper Research Journal, 25(1), 18-39.

Lee, A. M., Lewis, S. C., \& Powers, M. (2014). Audience clicks and news placement: A study of time-lagged influence in online journalism. Communication Research, 41(4), 505-530. DOI: http://dx.doi. org/10.1177/0093650212467031

Lee, M.-H., \& Han, E.-K. (2006). Competition: Hollywood versus domestic films: Release strategies of Hollywood films in South Korea. International Journal on Media Management, 8(3), 125-133. DOI: http://dx.doi. org/10.1207/s14241250ijmmo803_3

Li, T., \& Calantone, R. J. (1998). The impact of market knowledge competence on new product advantage: Conceptualization and empirical examination. Journal of Marketing, 62(4), 13-29. DOI: http://dx.doi. org/10.2307/1252284

MacGregor, P. (2007). Tracking the online audience: Metric data start a subtle revolution. Journalism Studies, 8(2), 280-298. DOI: http://dx.doi. org/10.1080/14616700601148879
McKelvie, A., \& Wiklund, J. (2006, May). Innovation in new media firms. Paper presented at the World Media Economics and Management Conference, Beijing, China.

McKelvie, A., \& Wiklund, J. (2008). Understanding innovation in new and young media firms. In C. Dal Zotto \& H. L. van Kranenburg (Eds.), Management and innovation in the media industry (pp. 15-35). Cheltenham: Edward Elgar.

McManus, J. H. (1994). Market-driven journalism: Let the citizen beware? Thousand Oaks, CA: Sage.

Mitchelstein, E., \& Boczkowski, P. J. (2009): Between tradition and change: A review of recent research on online news production. Journalism, 1O(5), 562-586.

Naldi, L., \& Picard, R. G. (2012). "Let's start an online news site": opportunities, resources, strategy, and formational myopia in startups. Journal of Media Business Studies, 9(4), 69-97.

Narver, J. C., \& Slater, S. F. (1990). The effect of a market orientation on business profitability. Journal of Marketing, 54(4), 20-35. DOI: http://dx.doi. org/10.2307/1251757

Nielsen, R. K. (2016): The business of news. In T. Witschge, C. W. Anderson, D. Domingo, \& A. Hermida (Eds.), The Sage handbook of digital journalism (pp. 51-67). London: Sage. 
Noble, C. H., Sinha, R. K., \& Kumar, A. (2002). Market orientation and alternative strategic orientations: A longitudinal assessment of performance implications. Journal of Marketing, 66(4), 25-39. DOI: http:// dx.doi.org/10.1509/jmkg.66.4.25.18513

Ordanini, A., \& Maglio, P. P. (2009). Market orientation, internal process, and external network: A qualitative comparative analysis of key decisional alternatives in the new service development. Decision Sciences, 4O(3), 601-625. DOI: http://dx.doi.org/10.1111/j.15405915.2009.00238.x

Raviola, E. (2012): Exploring organizantional framings. Information, Communication \& Society, 15(6), 932-958. DOI: http://dx.doi.org/ 10.1080/1369118X.2012.696273

Raviola, E. \& Hartmann, B. (2009): Business perspectives on work in news organizations. Journal of Media Business Studies, 6(1), 7-36. DOI: http://dx.doi.org/ 10.1080/16522354.2009.11073477

Rochet, J.-C., \& Tirole, J. (2006). Two-sided markets: A progress report. RAND Journal of Economics, 37(3), 645-667. DOI: http://dx.doi. org/10.1111/j.1756-2171.2006.tbooo36.x

Shaver, M. A., \& Lacy, S. (1999). The impact of intermedia and newspaper competition on advertising lineage in daily newspapers. Journalism \& Mass Communication Quarterly, 76(4), 729-744
Shrikhande, S. (2001). Competitive strategies in the internationalization of television: CNNI and BBC World in Asia. Journal of Media Economics, 14(3), 147-168. DOI: http://dx.doi.org/10.1207/S15327736ME1403_2 Simons, H. (2009). Case study research in practice. London: Sage.

Slater, S. F., \& Narver, J. C. (1995). Market orientation and the learning organization. Journal of Marketing, 59(3), 63-74. DOI: http://dx.doi.org/10.2307/1252120 Sommer, C. (2015). Media brands and the advertising market: Exploring the potential of branding in media organizations' B2B relationships. In G. Siegert, K. Förster, S. M. Chan-Olmsted, \& M. Ots (Eds.), Handbook of media branding (pp. 97-110). Berlin: Springer.

Sommer, C., \& Krebs, I. (2016). Market orientation in news media: How learning about and responding to readers and competitors impacts success. Journal of Applied Journalism \& Media Studies, 5(3), 441-464. Sommer, C., \& von Rimscha, M. B. (2014). Jenseits von traditionellen Mediengattungen: Die transmediale Angebotsmatrix. In H. Rau (Ed.), Medieno konomie: Vol. 7. Digitale Da“ mmerung. Die Entmaterialisierung der Medienwirtschaft (pp. 247-265). Baden-Baden: Nomos.

Stake, R. E. (1995). The art of case study research. Thousand Oaks, CA: Sage.
Tandoc, E. C. (2014a). Journalism is twerking? How web analytics is changing the process of gatekeeping. New Media \& Society, 16(4), 559-575. DOI: http://dx.doi. org/10.1177/1461444814530541

Tandoc, E. C. (2014b). Why web analytics click: Factors affecting the ways journalists use audience metrics. Journalism Studies, 16(6), 1-18. DOI: http://dx.doi.or g/10.1080/1461670X.2014.946309

Tandoc, E. C. \& Ferrucci, P. (2014, August). A tale of two newsrooms: How market orientation influences web analytics use. Paper presented at the meeting of the Association for Education in Journalism and Mass Communication, Montreal. Retrieved from http:// www.academia.edu/8264434/A_tale_of_two_newsrooms_How_market_orientation_influences_web_ analytics_use

Tandoc, E. C., \& Thomas, R. J. (2014). The ethics of web analytics: Implications of using audience metrics in news construction. Digital Journalism, 3(2), 1-16. DOI: http://dx.doi.org/10.1080/21670811.2014.9091 22

Usher, N. (2013). Al Jazeera English online: Understanding web metrics and news production when a quantified audience is not a commodified audience. Digital Journalism, 1(3), 1-17. DOI: http://dx.doi.org/10.108 o/21670811.2013.801690 
van Weezel, A. (2010). Creative destruction: Why not researching entrepreneurial media? International Journal on Media Management, 12(1), 47-49. DOI: http:// dx.doi.org/10.1080/14241270903558442

von Rimscha, M. B., \& Sommer, C. (2016). Fallstudien. In S. Averbeck-Lietz \& M. Meyen (Eds.), Handbuch nicht standardisierte Methoden in der Kommunikationswissenschaft (pp. 369-384). Wiesbaden: Springer VS.

Varian, H. R., Farrell, J., \& Shapiro, C. (2011). The economics of information technology: An introduction ( $7^{\text {th }}$ ed.). Cambridge: Cambridge University Press.

$\mathrm{Vu}, \mathrm{H}$. T. (2014). The online audience as gatekeeper: The influence of reader metrics on news editorial selection. Journalism, 15(8), 1094-1110. DOI: http://dx.doi. org/10.1177/1464884913504259

Weaver, D. H., Beam, R. A., Brownlee, B. J., Voakes, P. S., \& Wilhoit, G. C. (2007). The American journalist in the $21^{\text {st }}$ century: US news people at the dawn of a new millennium. Mahwah, NJ: Lawrence Erlbaum.

Westlund, O., \& Lewis, S. C. (2014): Agents of media innovations: Actors, actants, and audiences. The Journal of Media Innovations, 1(2), 10-35
Wildman, S. S. (2006). Paradigms and analytical frameworks in modern economics and media economics. In A. B. Albarran, S. M. Chan-Olmsted, \& M. O. Wirth (Eds.), Handbook of media management and economics (pp. 67-90). Mahwah, NJ: Lawrence Erlbaum.

Wirtz, B. W., Pelz, R., \& Ullrich, S. (2011). Marketing competencies of publishers and ad sales success. Journal of Media Business Studies, 8(1), 23-46.

Wong, S. K. S., \& Tong, C. (2012). The influence of market orientation on new product success. European Journal of Innovation Management, 15(1), 99-121. DOI: http://dx.doi.org/10.1108/14601061211192852

Wren, B. M., Souder, W., \& Berkowitz, D. (2000). Market orientation and new product development in global industrial firms. Industrial Marketing Management, 29(6), 601-611. DOI: http://dx.doi.org/10.1016/ Soo19-8501(00)00120-6

Yin, R. K. (2009). Case study research: Design and methods ( $4^{\text {th }}$ ed.). Applied social research methods series: Vol. 5. Los Angeles: Sage. 